\title{
Effects of mercury intoxication on the response of horizontal cells of the retina of thraira fish (Hoplias malabaricus)
}

\section{C.L. Tanan ${ }^{1}$, D.F. Ventura ${ }^{1}$, J.M. de Souza ${ }^{1}$, S.R. Grotzner², M. Mela ${ }^{2}$, A. Gouveia Jr. ${ }^{3}$ and C.A. Oliveira-Ribeiro ${ }^{2}$}

\author{
${ }^{1}$ Departamento de Psicologia Experimental, Instituto de Psicologia, \\ Centro de Neurociências e Comportamento, Universidade de São Paulo, \\ São Paulo, SP, Brasil \\ 2Departamento de Biologia Celular, Universidade Federal do Paraná, \\ Curitiba, PR, Brasil \\ ${ }^{3}$ Departamento de Psicologia, Universidade Estadual Paulista Júlio de Mesquita Filho, \\ UNESP, Bauru, SP, Brasil
}

\author{
Correspondence \\ C.L. Tanan \\ Instituto de Psicologia, USP \\ Av. Professor Mello Moraes, 1721 \\ Bloco A, Sala D-9 \\ 05508-900 São Paulo, SP \\ Brasil \\ Fax: + 55-11-3091-4357 \\ E-mail: cltanan@ hotmail.com \\ Presented at the Symposium on \\ Sensory and Neuropsychological \\ Losses Due to Mercury Intoxication \\ and to $\mathrm{O}$ ther Neurodegenerative \\ Processes. Studies in Humans and \\ in Animal Models. Águas de Lindóia, \\ SP, Brazil, August 25-29, 2004. \\ Research supported by FAPESP to \\ D.F. Ventura (Proj. Temático No. \\ 02/12733-8), CAPES/PROCAD (No. \\ 0019/01), and CNPq. D.F. Ventura \\ is the recipient of a CNPq $1 \mathrm{~A}$ \\ research fellowship and C.L. Tanan \\ is the recipient of a M aster's \\ fellowship from FAPESP \\ (No. 03/02700-8).
}

Received April 27, 2005 Accepted March 20, 2006

\begin{abstract}
Methyl mercury (MeHg) is highly neurotoxic, affecting visual function in addition to other central nervous system functions. The effect of mercury intoxication on the amplitude of horizontal cell responses to light was studied in the retina of the fish Hoplias malabaricus. Intracellular responses were recorded from horizontal cells of fish previously intoxicated with $\mathrm{MeHg}$ by intraperitoneal injection (IP group) or by trophic exposure (T group). Only one retina per fish was used. The doses of $\mathrm{MeHg}$ chloride administered to the IP group were $0.01,0.05,0.1,1.0,2.0$, and $6.0 \mathrm{mg} / \mathrm{kg}$. The amplitudes of the horizontal cell responses were lower than control in individuals exposed to 0.01 ( $\mathrm{N}=4$ retinas), $0.05(\mathrm{~N}=2$ retinas) and $0.1 \mathrm{mg} / \mathrm{kg}(\mathrm{N}$ $=1$ retina), whereas no responses were recorded in the 1.0, 2.0, and 6.0 $\mathrm{mg} / \mathrm{kg}$ groups. T group individuals were fed young specimens of Astyanax sp previously injected with $\mathrm{MeHg}$ corresponding to 0.75 (N $=1$ retina $), 0.075(\mathrm{~N}=8$ retinas $)$ or $0.0075(\mathrm{~N}=4$ retinas $) \mathrm{mg} / \mathrm{kg}$ fish body weight. After 14 doses, one every 5 days, the amplitude of the horizontal cell response was higher than control in individuals exposed to 0.075 and $0.0075 \mathrm{mg} / \mathrm{kg}$, and lower in individuals exposed to $0.75 \mathrm{mg} / \mathrm{kg}$. We conclude that intoxication with $\mathrm{MeHg}$ affects the electrophysiological response of the horizontal cells in the retina, either reducing or increasing its amplitude compared to control, and that these effects are related to the dose and/or to the mode of administration.
\end{abstract}

\section{Introduction}

Mercury intoxication in humans and animals is caused in part by atmospheric pollution and in part by natural causes such as corrosion of the earth's crust, volcanic activity, or evaporation of large masses of water

\section{Key words}

- Methyl mercury

- Horizontal cells

- Electrophysiology

- Hoplias malabaricus

- Retina
(2700-6000 ton/year), as well as by direct human activities (3000 ton/year) (1). Many aquatic environments in the Amazon region have been exposed by gold mining activities (2-5).

Due to their position in the feeding chain, aquatic animals such as fish become intoxi- 
cated with methyl mercury $(\mathrm{MeHg}$ ) mainly through the gills and the trophic pathway. Trophic intoxication occurs at higher levels in carnivorous than in herbivorous or omnivorous species (4). Pinheiro et al. (6) found high concentrations of $\mathrm{MeHg}$ in carnivorous species of fish, and other investigators have reported elevated concentrations of $\mathrm{MeHg}$ in Brazilian fish $(2,4,5)$.

$\mathrm{MeHg}$ affects synaptic transmission both in the peripheral and the central nervous systems, and this action is mediated by several mechanisms (7). The visual system is an important target of mercury intoxication (812). Investigation of the neuro-ophthalmological aspects of the mercury intoxication that caused Minamata disease started with the measurement of the visual field performed by Iwata and Abe (8).

The effects of mercury intoxication on the retinae of vertebrates are still little known. In studies on the squirrel monkey, mercury vapor inhaled by the mother accumulated in several tissues of the neonate's retina - the optic nerve, the inner plexiform layer and the ganglion cells, - and was also concentrated in the pigment epithelium and in blood vessel walls $(13,14)$. It has also been observed that mercury accumulates in the rod photoreceptor cells of the monkey retina $(15,16)$. Cats intoxicated with mercury exhibited an increase in the amplitude of the bwave of the electroretinogram, and also a decrease in the response latency compared to untreated cats (17). In a pioneering study describing changes due to mercury exposure in the functioning of the retina, Fox and Sillman (18) showed that rods, but not cones, were affected in the electroretinogram of the frog. Their study, however, used mass action potentials in the two-flash technique to extract the rod responses by subtracting the mixed rod and cone response obtained with a flash from the pure cone response obtained with a second flash.

In fish there is little evidence of the effects of mercury exposure on vision. Hawry- shyn et al. (19) demonstrated a reduction of the behaviorally determined visual spectral sensitivity function in the rainbow trout injected intraperitoneally (ip) with MeHg. The reduction of sensitivity involved both photopic and scotopic mechanisms, in contrast to the previous results obtained by Fox and Sillman (18).

The present study investigated the activity of single retinal neurons in mercuryexposed Hoplias malabaricus fish. We studied the responses of monophasic horizontal cells of the fish retina, which correspond to morphological type H1 (20), with the purpose of evaluating cone impairment due to the effects of $\mathrm{MeHg}$ intoxication. Monophasic horizontal cells reflect the activity of cones, mainly of the L-type cones, and are also called luminosity horizontal cells, as opposed to chromaticity horizontal cells, since they are thought to process luminance information $(21,22)$. Due to the relative ease of recording from $\mathrm{H} 1$ horizontal cells compared to other retinal cells in the fish retina, these cells offer a good model for investigating impairment of the functions of the outer retina.

\section{Material and Methods}

\section{Experimental animals}

Specimens of thraira (Hoplias malabaricus), obtained from Toledo Station (a lake in the northwest of Paraná State, Brazil), approximately $30 \mathrm{~cm}$ in length, were maintained in glass aquaria (40 L) under constant aeration. An untreated control group $(\mathrm{N}=6$ retinas) and nine mercury-exposed groups were used. The IP groups were acclimated to the experimental conditions for 10 days and then received an intraperitoneal ( $i p)$ injection of $\mathrm{MeHg}$ (IP group) at one of the following doses: $0.01(\mathrm{~N}=4), 0.05(\mathrm{~N}=2)$, $0.1(\mathrm{~N}=1), 1.0(\mathrm{~N}=2), 2.0(\mathrm{~N}=4), 6.0$ $(\mathrm{N}=4) \mathrm{mg} / \mathrm{kg} \mathrm{MeHg}$, under anesthesia with $0.02 \% 3$-aminobenzoic acid ethyl ester. The 
retinas were analyzed 15 days after ip injection. Fish from the other treated group, exposed to mercury through feeding (trophic or $\mathrm{T}$ group), were acclimated to the experimental conditions for 30 days ( 1 fish per 30$\mathrm{L}$ aquarium containing dechlorinated tap water, at a temperature of $21 \pm 2^{\circ} \mathrm{C}$ and under a 12:12-h photoperiod). The fish were fed young live specimens of Astyanax sp previously injected $i p$ with $0.1 \mathrm{~mL}$ of an aqueous solution of $\mathrm{MeHg}$. The $\mathrm{mg} / \mathrm{kg}$ doses were calculated for each thraira based on its weight. Since each thraira was kept in one aquarium, it was possible to determine with precision the number of Astyanax specimens ingested by each fish. The final dose was based on the total amount of MeHg ingested by the fish. This total amount was the sum of the mercury content that had been injected into 14 Astyanax fish eaten by the thraira. Three dose groups of 7 individuals each were exposed to $\mathrm{MeHg}\left(\mathrm{H}_{3} \mathrm{C}-\mathrm{Hg}^{+}\right)$. Doses of 0.75 , 0.075 , and $0.0075 \mathrm{mg} \mathrm{H}_{3} \mathrm{C}-\mathrm{Hg}^{+} / \mathrm{kg}$ wet thraira weight, corresponding to each of the three groups, were administered every 5 days (corresponding approximately to a daily dose exposure of $0.015 \mathrm{mg} \mathrm{MeHg} / \mathrm{kg}$ ). After 14 doses of $\mathrm{MeHg}$, retinas exposed to $0.75(\mathrm{~N}=$ 1), $0.075(\mathrm{~N}=8)$, and $0.0075 \mathrm{mg} / \mathrm{kg}(\mathrm{N}=4)$, were used for electrophysiology.

\section{Preparation}

Intracellular recordings were obtained from isolated retinae. After enucleation, the anterior part of the eye was removed by hemisection and the retina was flattened on Millipore paper, with the photoreceptors facing up, after removal of the sclera and choroid. The preparation was placed inside a Faraday cage and the retina was maintained alive by a constant flow of Ringer's solution containing sodium HEPES for fish of the following composition: $1.5 \mathrm{mM}$ $\mathrm{CaCl}_{2}, 72 \mathrm{mM} \mathrm{NaCl}, 1.56 \mathrm{mM} \mathrm{KCl}, 0.6 \mathrm{mM}$ $\mathrm{MgCl}_{2}, 7.2 \mathrm{mM}$ HEPES, and $7.2 \mathrm{mM}$ glucose.

\section{Recording equipment}

The electrophysiological responses of the retinal cells were recorded through glass microelectrodes (Boron-silicate, WPI, New Haven, CT, USA) filled with a conductive solution of $3 \mathrm{M} \mathrm{KCl}$, with high tip resistances (200 to $400 \mathrm{MOhms}$ ). The microelectrodes were prepared immediately before the experiments with a Sutter model P-2000 laser puller. A David-Kopf (Tujunga, CA, USA) hydraulic micropositioner was used to advance the electrode in constant steps (2.5 $\mu \mathrm{m})$ to penetrate cells.

Recordings were made with a WPI model 767 intracellular amplifier monitored on a Tektronix D13 oscilloscope (Alta Loma, CA, USA), and recorded on magnetic tape initially with an HP model 3968A analogue recorder and later with a Cygnus CDAT4 (Delaware Water Gap, PA, USA) digital recorder. Recorded responses were transferred off-line to paper using a Gould model 3000 (Cleveland, OH, USA) chart recorder, and response parameters were measured using an in-house computer program for data acquisition (Data Acquisition Devices, model: PCI-MIO-16E-1), with a National Instruments card (Austin, TX, USA).

\section{Optical stimulation}

The system consisted of a $75-\mathrm{W}$ xenon light source, a monochromator and an allquartz optical system that projected a disk of light onto the preparation (for details, see Ref. 23). The intensities, wavelengths and diameters of the light stimulus were controlled electromechanically by a computer. The optical stimulation was programmed to emit appropriate sequences of stimuli for the identification and measurement of the characteristics of the cells penetrated.

The xenon lamp coupled to the monochromator generated the light stimulus. The light was transmitted through a fiber optic bundle, an electromagnetic shutter, a neutral 
density filter to reduce the luminous intensity (Starna, Atascadero, CA, USA, model $522,0-4 \log$ ), a diaphragm of variable diameter that projects a circular spot of light from 20 to $1700 \mu \mathrm{m}$ onto the retina and an optical system composed of two lenses that focus the image of the diaphragm onto the retina. Calibration of the luminous source is made periodically, with an International Light radiometer model IL 1700 and a SED 033 photodetector (both from Peabody, MA, USA). Calibration was performed for each of the 205 positions of the neutral filter at each of the 101 wavelengths of the monochromator, in 4-nm steps from 300-700 nm.

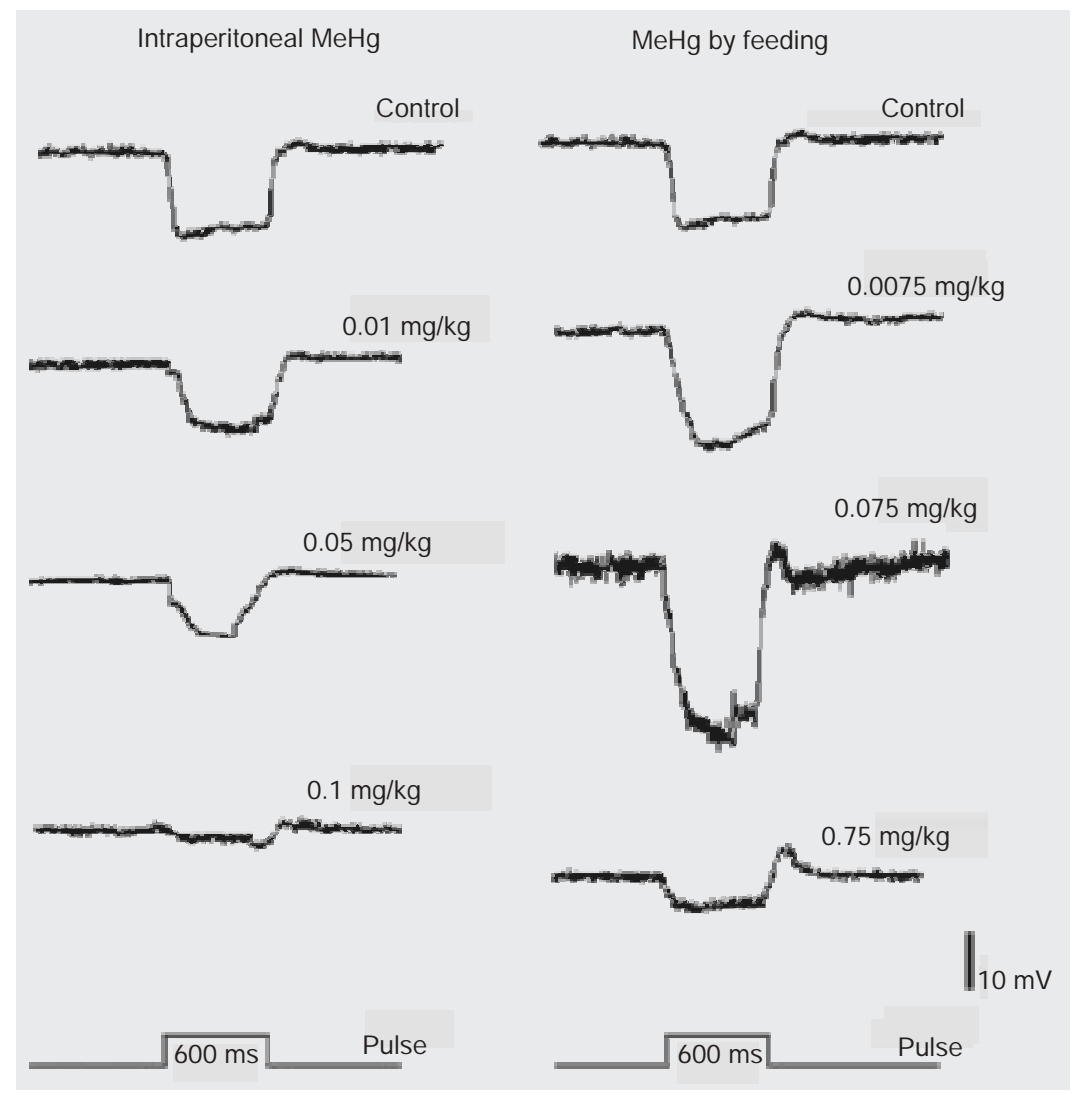

Figure 1. Intracellular recordings obtained in monophasic horizontal cells in response to 640 -nm flashes of $3 \times 10^{13} \mathrm{q} \mathrm{s}^{-1}\left(\mathrm{~cm}^{2}\right)^{-1}$. For the group receiving intraperitoneal injections of $\mathrm{MeHg}$ there was a decrease of the response amplitude with increasing doses. Different results were obtained for the fish that received mercury through feeding. They showed an increase in the response amplitude with the increase of the dose at low doses and a decrease of the responses amplitude with the highest doses.

\section{Stimulation procedure}

The preparation was kept in a lightshielded cage in which background light was very low. To find cells, we used a continuously flashing light of medium intensity, thus adapting the stimulated region of the retina (a spot of about $1.5 \mathrm{~mm}$ in diameter, centered on the electrode tip).

After penetrating a cell, we immediately turned off the probing light and presented a series of stimuli of increasing diameters, at a fixed wavelength, for the determination of the type of cell penetrated. Next, a stimulation program generated four 400-ms pulses at $370,450,540$, and $640 \mathrm{~nm}$, with intervals of $500 \mathrm{~ms}$ between each pulse. This series of four pulses was presented at three different intensities $(-1,-2$, and $-3 \log )$ relative to the maximum intensity $\left(3 \times 10^{13} \mathrm{q} \mathrm{s}^{-1}\left(\mathrm{~cm}^{2}\right)^{-1}\right)$. The maximum diameter of the light spot $(1500 \mu \mathrm{m})$ was used. If the cell's responses and baseline were stable, a spectral sequence was presented at a larger number of wavelengths, extending up to $700 \mathrm{~nm}$. With this more detailed series, the peak frequency could be determined more precisely.

\section{Statistical analysis}

One-way ANOVA using the KruskalWallis and Duncan post hoc tests from the Statistica 6.0 (Stat Soft, Inc., Tulsa, OK, USA) statistical analysis program was used for data analysis. In this analysis the averages of the amplitudes and latencies obtained for each retina of the treated and control groups were compared, with the level of significance set at $\mathrm{P}<0.05$.

\section{Results}

No electrophysiological responses were observed in the retinas of fish injected with $1.0,2.0$, or $6.0 \mathrm{mg} \mathrm{MeHg} / \mathrm{kg}$. Examples of intracellular recordings of monophasic horizontal cell responses from the groups in- 
jected with lower doses of $\mathrm{MeHg}$, for which it was possible to record activity, are shown in Figure 1. The left column presents the responses of the IP group and the right column those of the T group. The corresponding dose is indicated next to the response trace. A horizontal cell response from a retina from the control group is also shown at the top of each column; the same trace is displayed for both the IP and T groups. Notice that the concentration range was 10 -fold for the IP group and 100-fold for the T group.

In the control group 19 horizontal cells were recorded from 6 retinas. The amplitudes of the responses to flashes of $3 \times 10^{13} \mathrm{q}$ $\mathrm{s}^{-1}\left(\mathrm{~cm}^{2}\right)^{-1}$ had an average value of $-18.4 \pm$ $7.7 \mathrm{mV}$ at $640 \mathrm{~nm}$. The response amplitude to this stimulus $\left(3 \times 10^{13} \mathrm{q} \mathrm{s}^{-1}\left(\mathrm{~cm}^{2}\right)^{-1}\right.$ at 640 $\mathrm{nm}$ ) will be compared below for all experimental conditions. Figure 2 presents the av- erages and standard deviations of the response amplitudes obtained at all wavelengths and intensities under the different experimental conditions.

In retinas from fish exposed to $0.1 \mathrm{mg}$ $\mathrm{MeHg} / \mathrm{kg}$, two cells recorded from the same retina responded with a smaller amplitude to 640-nm flashes at -1 log compared to the control group (average response amplitude $640 \mathrm{~nm},-1 \log =-6.48 \pm 1.7 \mathrm{mV}, \mathrm{P}=0.495$ ). In addition to almost complete absence of electrophysiological responses, extensive hemorrhaging was observed in the choroids of all the retinas from the IP group exposed to $0.1,1.0,2.0$, and $6.0 \mathrm{mg} \mathrm{MeHg} / \mathrm{kg}$. Fish from these groups were less responsive to handling compared to control. It was only at the two lowest ip $\mathrm{MeHg}$ doses used that a higher number of intracellular responses were recorded. Three cells from 2 retinas were

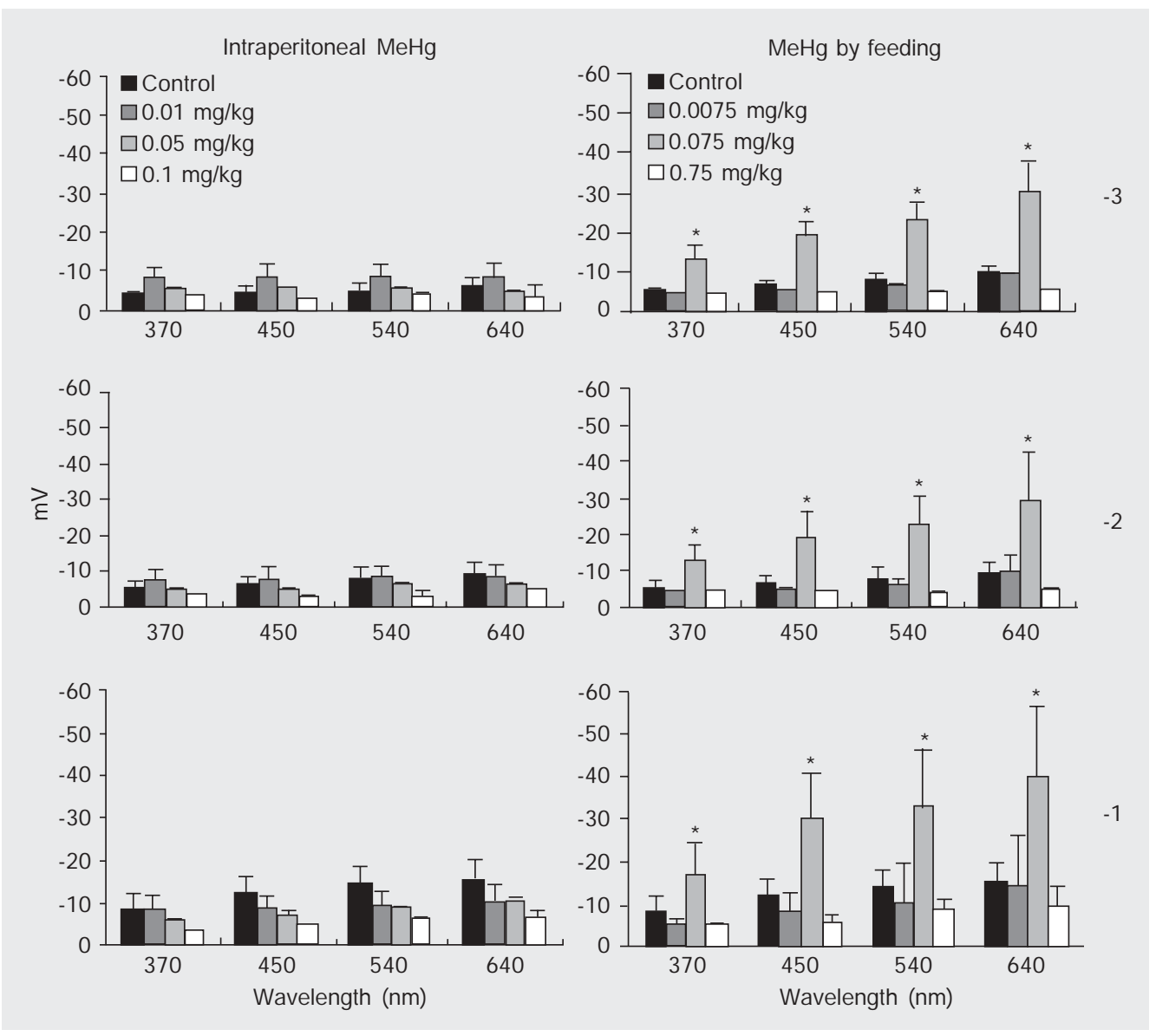

Figure 2. Response amplitudes of the retinal horizontal cells at four different wavelengths (abscissa) and three light intensities (indicated by the attenuation log values from the original at the right of the graphs). The bars represent the mean $\pm S D$. A statistically significant difference was observed between the control group and the group intoxicated with $0.075 \mathrm{mg} / \mathrm{kg}$ through feeding. For all groups there was a similar pattern of the decrease in amplitude decrease with the increase of the $\log$ attenuation indicated by the numbers on the right side of the figure. 
recorded in the $0.05-\mathrm{mg} \mathrm{MeHg} / \mathrm{kg}$ IP group (average response amplitude: $640 \mathrm{~nm},-1 \mathrm{log}$ $=-10.66 \pm 0.78 \mathrm{mV}, \mathrm{P}=0.598)$. In the $0.01-$ $\mathrm{mg} \mathrm{MeHg} / \mathrm{kg}$ IP group, recordings were obtained for 8 cells from 4 retinas (average response amplitude: $640 \mathrm{~nm},-1 \log =-10.33$ $\pm 3.66 \mathrm{mV}, \mathrm{P}=0.585$ ).

In the $\mathrm{T}$ group exposed to $0.75 \mathrm{mg} \mathrm{MeHg} /$ $\mathrm{kg}$, 6 cells were recorded from one retina (average response amplitude: $640 \mathrm{~nm},-1 \mathrm{log}$ $=-9.7 \pm 4.6 \mathrm{mV}, \mathrm{P}=0.658)$ and in the 0.075 $\mathrm{mg} \mathrm{MeHg} / \mathrm{kg} \mathrm{T}$ group, 27 cells were recorded from 8 retinas (average response amplitude: $640 \mathrm{~nm},-1 \log =-40.31 \pm 17.49$ $\mathrm{mV}, \mathrm{P}=0.009$ ). These responses had the same characteristics as those recorded from the control group, but their amplitudes were higher than control. Eighteen cells from 4 retinas were recorded in the $0.0075-\mathrm{mg}$ $\mathrm{MeHg} / \mathrm{kg} \mathrm{T}$ group (average response amplitude: $640 \mathrm{~nm},-1 \log =-15.0 \pm 12.09 \mathrm{mV}, \mathrm{P}=$ 0.950 ).

The mean amplitudes recorded at all doses for the IP and T groups, as well as those for the control group, are presented in Figure 2. Response amplitudes increased with intensity at all wavelengths. The response amplitude peaked at $640 \mathrm{~nm}$, which is characteristic of monophasic horizontal cells. The amplitude differences as a function of intensity were more apparent at the highest intensity and even more for the intermediate dose of the $\mathrm{T}$ group.

\section{Discussion}

We have recorded electrophysiological responses of horizontal cells in the species H. malabaricus. The horizontal cells that we recorded from were basically characterized by their large receptive fields and slow graded potentials, similar to those recorded in several other species such as the goldfish $(\mathrm{Ca}$ rassius auratus) (22,24), carp (Cyprinus carpio) (21), or the Amazonian species Prochilodus lineatus (25). The characteristics of the spatial response and the response to dif- ferent light intensities were similar to those observed in many other species of fish.

In both the IP and T groups the monophasic horizontal cell responses were affected by intoxication with $\mathrm{MeHg}$ in a dose-dependent way. This finding extends results that contradict the report that the neurotoxic action of mercury on the retina is restricted to the rod system. We observed here that the cone system is affected, and furthermore that it is affected differently by different administration procedures. Intraperitoneal injection is an acute procedure, while the $\mathrm{T}$ group is submitted to a slow, chronic intoxication procedure, much closer to what could happen in the natural habitat. In the group intoxicated with ip injection, no responses were recorded at the three highest doses, possibly due to widespread cellular damage caused by intoxication. The damage caused by the intoxication was also evident in the extensive hemorrhage of the choroids and in the alteration of the behavior of the intoxicated fish. Some responses were recorded in the groups intoxicated with injections of 0.1, 0.05 , and $0.01 \mathrm{mg} / \mathrm{kg} \mathrm{MeHg}$, but they were much more difficult to obtain, and had much smaller amplitudes compared to control. We conclude that intoxication with $\mathrm{MeHg}$ is definitely harmful to retinal horizontal cells, and that larger doses eliminate all intracellular responses.

The ip design used here was applied according to Hawryshyn et al. $(19,26)$ who determined scotopic sensitivity behaviorally in the rainbow trout (Salmo gairdneri Richardson), a species that inhabits colder waters. These investigators injected the fish with 4.6 and $6.2 \mathrm{mg} \mathrm{MeHg} / \mathrm{kg}$ and obtained reliable behavioral responses. The same doses applied to thrairas resulted in behavioral unresponsiveness to handling and in complete absence of electrophysiological activity in the retina, suggesting a higher sensitivity of tropical fish species to mercury exposure, as also reported by de Oliveira Ribeiro et al. (27), as compared to the 
species used in the study by Hawryshyn et al. $(19,26)$. According to the same authors, this could be due to the higher metabolic rate of tropical species, resulting in damage to the retina and in the impossibility of intracellular recordings.

The trophic exposure group was designed according to the procedure used by Rabitto et al. (28), in which the doses used simulated the conditions found in nature. As reported by Kehrig et al. (29), it is estimated that carnivorous fish from the Amazon region, used daily in the human diet, have about 0.5 $0.9 \mathrm{mg} \mathrm{MeHg} / \mathrm{kg}$, a higher concentration than used in the present study.

The retina recordings in the trophic preparations had larger amplitudes than those of the control group. This result suggests that for very low doses there is an excitability effect, followed by a decrease in response amplitude at intermediate concentrations and finally the cessation of activity with high doses. Increases in electrophysiological responses from the retina have also been found in the electroretinograms of cats intoxicated with mercury (17) and of humans intoxicated with lead (30).

At the same time as the present study, a morphological study was carried out on the effects of $\mathrm{MeHg}$ intoxication on the retina $(31,32)$. For each retina used in an electrophysiological experiment the other retina from the same fish was used for the morphological study. Morphological analysis did not suggest a complete absence of activity in the exposed cells, as found in the electrophysiological experiments. In fish injected with the two highest ip doses (2 and $6 \mathrm{mg}$ $\mathrm{MeHg} / \mathrm{kg}$ ) a dose-dependent reduction of the number of cells with immunoreactivity to parvalbumin was detected, probably amacrine and displaced amacrine cells $(31,32)$ and bipolar cells of the ON type, with immunoreactivity to protein kinase $\mathrm{C}$. The quantification of these data should provide a better understanding of the electrophysiological data.

An explanation of the opposite effects obtained in the IP and T groups is the Ushaped dose-response curve of synaptic transmission of the MeHg effect. As reported by some investigators, one of the primary effects of $\mathrm{MeHg}$ on synaptic transmission is the increase, followed by a decrease, of the spontaneous liberation of neurotransmitters, as well as a decrease in the liberation of neurotransmitters activated by the nerve impulses (33-35). The reduction of the provoked neurotransmitter release has been associated with a decrease in the amount of neurotransmitter available for liberation (36), with the blocking of the $\mathrm{Ca}^{2+}$-dependent voltage channels that control the exocytosis of synaptic vesicles, and with the decrease in the excitability of the neuronal membrane (37-40).

The present findings constitute the first intracellular demonstration of the retinal effects of $\mathrm{MeHg}$. They demonstrate that the cone system is profoundly affected by the intoxication, thus confirming previous suggestions from the literature regarding fish $(19,25)$ and humans $(9,12)$. The effects ranged, in a dose-dependent manner, from complete elimination of the response to response reduction in the acute intoxication procedure, while in the chronic procedure, they ranged from reduction of the response to a hypersensitive response at low doses. These effects are compatible with the findings that cone-mediated functions such as color vision and contrast sensitivity are affected by mercury intoxication in humans $(9,12)$. 


\section{References}

1. WHO (World Health Organization) IIPICS. Environmental Health Criteria 118 Inorganic Mercury. Geneva: World Health Organization; 1991.

2. Akagu $\mathrm{H}$, Malm O, Kinjo $Y$, Harada $M$, Branches FJ P, Pfeiffer WC, et al. Methylmercury pollution in the Amazon, Brazil. Sci Total Environ 1995; 175: 85-95.

3. Veiga MM, Hinton J, Lilly C. Mercury in the Amazon: a comprehensive review with special emphasis on bioaccumulation and bioindicators. Proc NIMD Forum 1999; 99: 19-39.

4. Lima APS, Müller RCS, Sarkis JES, Alves CN, Bentes MHS, Brabo $E$, et al. Mercury contamination in fish from Santarém, Pará, Brazil. Environ Res 2000; 83: 117-122.

5. Brabo ES, Santos EO, De J esus IM, Mascarenhas AF, Faial KF. Mercury contamination of fish and exposures of an indigenous community in Pará State, Brazil. Environ Res 2000; 84: 197-203.

6. Pinheiro MCM, Guimarães GA, Nakanishi J, Oikawa T, Vieira J L, Quaresma $M$, et al. Total mercury in hair samples of inhabitants of Tapajós River, Pará State, Brazil. Rev Soc Bras Med Trop 2000; 33: 181-184.

7. Atchison WD, Hare MF. Mechanisms of methylmercury-induced neurotoxicity. FASEB J 1994; 8: 622-629.

8. Iwata K, Abe H. Neuroophthalmological and pathological studies of organic mercury poisoning, "Minamata disease" in Japan. In: Tsubaki T, Takahashi H (Editors), Recent advances in Minamata disease studies. Methylmercury poisoning in Minamata and Niigata Japan. Tokyo: Kodansha; 1986. p 58-74.

9. Ventura DF, Costa MT, Costa MF, Berezovsky A, Salomao SR, Simoes $A L$, et al. Multifocal and full-field electroretinogram changes associated with color-vision loss in mercury vapor exposure. Vis Neurosci 2004; 21: 421-429.

10. Gobba F, Cavalleri A. Color vision impairment in workers exposed to neurotoxic chemicals. Neurotoxicology 2003; 24: 693-702.

11. Lebel J, Mergler D, Branches F, Lucotte M, Amorim M, Larribe F, et al. Neurotoxic effects of low-level methylmercury contamination in the Amazonian Basin. Environ Res 1998; 79: 20-32.

12. Silveira LCL, Damin ETB, Pinheiro $M C N$, Rodrigues $A R$, Moura ALA, Côrtes MIT, et al. Visual dysfunction following mercury exposure by breathing mercury vapour or by eating mercury-contaminated food. In: Mollon J D, Pokorny J, Knoblauch K (Editors), Normal and Defective Colour Vision. Oxford: Oxford University Press; 2003. p 407-417.

13. Berlin M, Grant CA, Hellberg J, Hellstrom J , Schult A. Neurotoxicity of methylmercury in squirrel monkeys. Cerebral cortical pathology, interference with scotopic vision, and changes in operant behavior. Arch Environ Health 1975; 30: 340-348.

14. Berlin M, Blomstrand C, Grant CA, Hamberger A, Trofast J. Tritiated methylmercury in the brain of squirrel monkeys. Arch Environ Health 1975; 30: 591-597.

15. Warfvinge $K$, Bruun A. Mercury distribution in the squirrel monkey retina after in utero exposure to mercury vapor. Environ Res 2000; 83: 102-109.

16. Warfvinge $\mathrm{K}$, Bruun A. Mercury accumulation in the squirrel monkey eye after mercury vapour exposure. Toxicology 1996; 107: 189-200.

17. Gitter S, Pardo A, Kariv N, Yinon U. Enhanced electroretinogram in cats induced by exposure to mercury acetate. Toxicology 1988; 51 : 67-76.

18. Fox DA, Sillman AJ. Heavy metals affect rod, but not cone, photoreceptors. Science 1979; 206: 78-80.
19. Hawryshyn CW, Mackay WC, Nilsson TH. Methyl mercury induced visual deficits in rainbow trout. Can J Zool 1982; 60: 3127-3133.

20. Stell WK, Lightfoot DO. Color-specific interconnections of cones and horizontal cells in the retina of the goldfish. J Comp Neurol 1975; 159: 473-502.

21. Kaneko A. The functional role of retinal horizontal cells. Jpn J Physiol 1987; 37: 341-358.

22. Kamermans $M$, Kraaij $D$, Spekreijse $H$. The dynamic characteristics of the feedback signal from horizontal cells to cones in the goldfish retina. J Physiol 2001; 534: 489-500.

23. Ventura DF, De Souza J M, Devoe RD, Zana Y. UV responses in the retina of the turtle. Vis Neurosci 1999; 16: 191-204.

24. Joselevitch C. Visão no ultravioleta em Carassius auratus (Ostariophysi, Cypriformes, Cyprinidae): estudo eletrofisiológico do sistema cone - células horizontais. [Master's thesis]. São Paulo: Instituto de Psicologia, USP; 1999.

25. Takase E. Aspectos biológicos da visão no ultravioleta em beija-flor Eupetomena macroura e nos peixes Corimbata prochilodus líneatus e Dace tribolodon hakonensis. [Doctoral thesis]. São Paulo: Instituto de Psicologia, USP; 1997.

26. Hawryshyn CW, Mackay WC. Toxicity and tissue uptake of methylmercury administered intraperitoneally to rainbow trout (Salmo gairdneri Richardson). Bull Environ Contam Toxicol 1979; 23: 79-86.

27. de Oliveira Ribeiro CA, Belger L, Pelletier E, Rouleau C. Histopathological evidence of inorganic mercury and methyl mercury toxicity in the arctic charr (Salvelinus alpinus). Environ Res 2002; 90: 217225.

28. Rabitto IS, Alves Costa J R, Silva de Assis HC, Pelletier EE, Akaishi $F M, A$ njos $A$, et al. Effects of dietary $P b(I I)$ and tributyltin on neotropical fish, Hoplias malabaricus: histopathological and biochemical findings. Ecotoxicol Environ Saf 2005; 60: 147-156.

29. Kehrig HA, Malm O, Akagi H, Guimaraes J R, Torres J P. Methylmercury in fish and hair samples from the Balbina Reservoir, Brazilian Amazon. Environ Res 1998; 77: 84-90.

30. Rothenberg SJ, Schnaas L, Salgado-Valadares M, Casaneuva E, Geller AM, Hudnell HK, et al. Increased ERG a- and b-wave amplitudes in 7- to 10-year old children resulting from prenatal lead exposure. Invest Ophthalmol Visual Sci 1999; 43: 2036-2044.

31. Lima SM, Bonci DM, Grotzner SR, Ribeiro CA, Ventura DF. Loss of amacrine cells in MeHg-treated retinae in a tropical fish. Invest Ophthalmol Vis Sci 2003; 44: E-Abstract 5172 (Abstract).

32. Bonci DMO, de Lima SMA, Grötzner $S R$, Oliveira-Ribeiro $C A$, Hamassaki DE, Ventura DF. Losses of PV-IR amacrine and PKC-IR bipolar cells caused by methylmercury chloride intoxication in the retina of the tropical fish Hoplias malabaricus. Braz J Med Biol Res 2006; 39: 405-410.

33. J uang MS, Yonemura K. Increased spontaneous transmitter release from presynaptic nerve terminal by methylmercuric chloride. Nature 1975; 256: 211-213.

34. Yuan $Y$, Atchison WD. Disruption by methylmercury of membrane excitability and synaptic transmission of CA1 neurons in hippocampal slices of the rat. Toxicol Appl Pharmacol 1993; 120: 203-215.

35. Shrivastav BB, Brodwick BS, Narahashi T. Methylmercury: effects on electrical properties of squid axon membranes. Life Sci 1976; 18: 1077-1081.

36. Atchison WD, Narahashi T. Methylmercury-induced depression of neuromuscular transmission in the rat. Neurotoxicology 1982; 3: 37-50. 
37. Atchison WD, Joshi U, Thornburg JE. Irreversible suppression of calcium entry into nerve terminals by methylmercury. J Pharmacol Exp Ther 1986; 238: 618-624.

38. Traxinger DL, Atchison WD. Reversal of methylmercury-induced block of nerve-evoked release of acetylcholine at the neuromuscular junction. Toxicol Appl Pharmacol 1987; 90: 23-33.

39. Kauppinen RA, Komulainen $\mathrm{H}$, Taipale $\mathrm{H}$. Cellular mechanisms underlying the increase in cytosolic free calcium concentration induced by methylmercury in cerebrocortical synaptosomes from guinea pig. J Pharmacol Exp Ther 1989; 248: 1248-1254.

40. Shafer TJ, Atchison WD. Block of ${ }^{45} \mathrm{Ca}^{2+}$ uptake into synaptosomes by methylmercury: $\mathrm{Ca}^{2+}$ - and $\mathrm{Na}^{+}$-dependence. J Pharmacol Exp Ther 1989; 248: 696-702. 